\title{
Fiscal Discipline and the Successful Completion of Municipal Projects: The Case of City of Tshwane
}

\author{
Taola Simon Shai ${ }^{1}$, Zeleke Worku $^{1, *} \&$ Mammo Muchie $^{1}$ \\ ${ }^{1}$ Tshwane University of Technology Business School, 159 Nana Sita Street, Pretoria 0001, \\ South Africa \\ *Corresponding author: Tshwane University of Technology Business School, 159 Nana Sita \\ Street, Pretoria 0001, South Africa. E-mail: ShaiST@tut.ac.za
}

Received: June 26, 2019 Accepted: July 17, 2019 Published: August 5, 2019

doi: 10.5296/erm.v5i1.15214 URL: https://doi.org/10.5296/erm.v5i1.15214

\begin{abstract}
Kaiser, Crother, Kelly, Luiselli, O’Shea, Ota, Passos, Schleip and Wuster (2013) have shown the relationship between fiscal discipline and the successful completion of municipal projects in Sub-Saharan African countries. The study aims to assess and evaluate the degree of fiscal discipline exercised by employees of the City of Tshwane on municipal finance. Financial practitioners working in the City of Tshwane are required to comply with regulations and guidelines stipulated in the South African Municipal Finance Management Act (Act number 56 of 2003). Data was collected from a stratified random sample of 146 employees of the City of Tshwane who were responsible for providing financial services to customers. Data was collected by using a structured, pre-tested and validated questionnaire of study. Statistical methods such as frequency tables, cross-tab analyses and ordered probit regression were used for performing data analyses. Efficiency in financial management was assessed by assessing the degree of adherence of employees to the Municipal Finance Management Act (MFMA) based on a composite index defined by Kaiser, Crother, Kelly, Luiselli, O'Shea, Ota, Passos, Schleip \& Wuster (2013). The study showed that 89\% of the 146 employees who were selected for the study demonstrated adequate adherence to the Act, whereas $11 \%$ of employees failed to do so by the same standards. The study found that the degree of adherence of employees to the MFMA was significantly influenced by 3 factors. These 3 factors were degree of skills in financial accounting and auditing, duration of service, and degree of job satisfaction, in a decreasing order of strength. The results indicated a robust association between fiscal discipline and the successful completion of municipal projects.
\end{abstract}

Keywords: City of Tshwane, Fiscal discipline, Project management, Probit regression 


\section{Introduction and Background of Study}

Kaiser, Crother, Kelly, Luiselli, O’Shea, Ota, Passos, Schleip and Wuster (2013) have shown the relationship between fiscal discipline and the successful completion of municipal projects in Sub-Saharan African countries. The study aims to assess and evaluate the degree of fiscal discipline exercised by employees of the City of Tshwane on municipal finance. Financial practitioners working in the City of Tshwane are required to comply with regulations and guidelines stipulated in the South African Municipal Finance Management Act (Act number 56 of 2003). The aim of study was to assess the relationship between the degree of adherence to the South African Municipal Finance Management Act (Act number 56 of 2003) and customer satisfaction in the quality of municipal services provided to customers living and conducting business in the City of Tshwane. The purpose of the Municipal Finances Management Act (MFMA) is to ensure optimal service delivery at municipal level. The Act is suitable for promoting social and economic developments at all South African municipalities and local governments. The Act stipulates sound financial, accounting and auditing procedures to be followed by all municipalties in South Africa. The Act is based on norms and standards to be followed by all South African municipalities in the course of service delivery. The Act is designed to ensure optimal utilisation of municipal finances and resouces. The norms and standards stipulated in the Act enable assessors to evaluate compliance by employees.

According to Evans (2011:51) and Atkinson (2012: 47-56), overall productivity in municipal service delivery depends on sound financial management. In this regard, the sound and sustainable management of the financial affairs of municipalities and other institutions in the local sphere of government must be followed. The MFMA Act requires adherence to norms and standards that are set out by the South African Department of Finance as a means of ensuring optimal service delivery. According to Beck and Demirguc-Kunt (2012: 2931-2943), the MFMA is designed for minimsing the unnecessary wastage of financial resouces at municipal level. The Act is also designed for ensuring efficient municipal service delivery in all local governments and municipalities in South Africa.

The study is vital for the City of Tshwane Metropolitan Municipality in view of the fact that finance will enhance light on the degree to which proper financial management and accounting procedures are followed in the municipality. There are few studies conducted in this area to date. As such, the study stands to contribute significantly to the body of knowledge in this area. The stakeholder theory (Atkinson, 2012: 47-56) suggests that failure to satisfy the expectations and demand of customers in municipalities has the potential for leading to dissatisfaction and disruption of service delivery. A stakeholder is defined as an individual, multiple or diverse groups who may exert influence over an organization whose behaviours may be influenced by the organization as well. Amit and Schoemaker (2013: 33-46) define the stakeholder as any group or individual who can affect or is affected by the achievement of the organization's objectives. Annual reports issued by the South African Auditor General (South African Auditor General, 2015) and the City of Tshwane (2015) for the financial year 2013/2014 indicate that finances and resources are not utilized and managed according to plans of actions that have been approved by the City of Tshwane. The root cause of this problem is lack of skills in sound financial management and lack of 
adherence to the MFMA Act. Both reports show that the municipality is losing finances due to lack of skills and competencies in accounting and financial management. In comparison to the City of Tshwane, the City of Cape Town has managed to receive an unqualified financial report by the Auditor General for the financial year 2011/2012 and 2012/2013. This seems to suggest that the City of Tshwane stands to benefit from taking vital lessons from the City of Cape Town (City of Cape Town, 2015).

\section{Objective of Study}

The overall objective of study was to identify and quantify key predictors of adherence to the South African Municipal Finance Management Act (Act number 56 of 2003) in the City of Tshwane. The study aims to explain the relationship between the quality of service delivery and the proper utilization of financial management and accounting procedures at municipal level in the City of Tshwane. The specific objective of study is to identify and quantify key factors that affect the degree to which proper accounting and financial management procedures are followed by employees working in the City of Tshwane Metropolitan Municipality.

\section{Literature Review}

According to Edoho (2015: 127-147), inability to manage municipal finances and resouces efficiently is a key obstacle to sustained growth and development in all Sub-Saharan African countries including South Africa. Gereffi and Sturgeon (2013) have pointed out that financial mismanagement and lack of respect for human rights are significantly associated in developing economies of the world. The study by Henrekson (2014: 511-528) has shown that financial mismanagement and the abuse of power are chronic causes of protests at municipal levels. Bhatt and Grover (2013: 253-277) efficient service delivery at municipal level is significantly dependent upon the ability to utilise municipal resources and finances optimally. Grant (2013: 114-135) has reported that the abuse of municipal finances is often caused by lack of effective mechanisms of financial control. The study conducted by Gumede (2012: 21-28) has shown that sustained economic development and growth requires efficient utilisation of municipal resources and finances. The principles of good corporate governance are closely associated with sound financial management (Novy-Marx \& Rauh, 2011: 1211-1249). Wade and Hulland (2013: 107-142) and Watson and Head (2010) have pointed out that results-based monitoring, evaluation and control mechanisms are essential for sound financial management at municipal level. Annual reports issued by the South African Chamber of Commerce and Industry (2018) and the South African National Department of Trade and Industry (2018) have shown that the capacity of the South African Government to alleviate abject poverty and unemployment depends upon the degree to which municipalities can utilise financial resources according to approved plans of action. In this regard, the Municipal Finances Management Act (MFMA) is referred to as a benchmark in the assessment of the proper utilisation of municipal resources and finances. Sound financial management is a measure of accountability and good governance according to Sarkar \& Batabyal (2011: 20-29), and refers to the efficient and effective 
management of money in a manner that enables the successful implementation of approved plans of action at the municipal level. According to Kovacevic (2012: 12-15) and Kirsten and Rogerson (2012: 29-59), the capacity of municipalities such as the City of Tshwane to manage finances optimally is an objective measure of good corporate governance. Customers of the City of Tshwane require a wide variety of finances services from the City of Tshwane. The general public, business enterprises and Government Departments based in the City of Tshwane depend upon the ability of the City of Tshwane to provide reliable, affordable and efficient financial services at all times. The significance of this function includes the capacity of employees of the City of Tshwane who are responsible for routine accounting, auditing and financial services to deliver efficient services at all times.

Efficient financial management requires the ability to constantly make decisions based on empirical evidence and according to approved plans of action (Ferreira \& Campher, 2010). Financial management reforms typically incorporate the following components, namely use of structured planning and programming as a means of evaluating and selecting ways of achieving desired objective; taking resource allocation decisions within the framework of a unified budget; integration of budgeting and accounting; encouragement of financial accountability; preparation of consolidated reports and measurement of outputs and inputs. The South African Municipal Finance Management Act (MFMA) is designed to ensure the proper expenditure of all revenues, assets and liabilities. International best practice shows that sound financial management by local governments and municipalities requires the availability of technical skills in financial management, accounting, auditing, as well as the enforcement of relevant rules and regulations on finance (Ja Skela \& Lo'nnqvist, 2011: 289-302). A review of the literature shows that the City of Tshwane lags behind the City of Cape Town with regards to sound financial management and utilization of resources that are allocated for the implementation of approved plans of action by municipalities (City of Tshwane, 2015).

According to Van der Waldt (2006: 129), the degree to which sound financial management, proper accounting and auditing are utilized by local governments and municipalities depends on the commitment made for good governance, transparency and the availability of technical skills in financial management. Based on a research conducted to assess the degree of productivity, Radnor and Barnes (2007: 385) pointed out that each approved project by local governments and municipalities must be accompanied by performance management agreements and the enforcement of rules and regulations on expenditures and auditing. Financial Management gives the directions of where the company is coming from and where finance is heading to, and channel the respondents to be accountable to the resources allocated to them (Novy-Marx \& Rauh, 2011). Hoque (2011: 59) highlights that accountability is an essential element in achieving good governance. He adds that, governments that do not have a long tradition of functioning under an operational system of accountability face the challenge of establishing a system of governance that ensures a responsive, equitable and effective government to its community. He stated that, lack of accountability has resulted in failure, poor political decisions and high incidence of corruption (Hoque, 2011: 59). 
According to Joshi (2010: 01), accountability is widely accepted as a key to service delivery improvements. What is interesting is that the importance of accountability comes from quite different ideological streams. According to Rieseneder (2008), transparency is generally defined as the principle of enabling the public to gain information about the operations and structures of a given entity. Finance reduces uncertainty and may help in reducing incidents of corruption among public officials. The principle of transparency underpins the needs for regulations to be clear, straightforward and accessible as possible in their drafting, promulgation, codification and dissemination (Rieseneder, 2008). Furthermore, Engelbrecht (2009: 20), outlines that, the board should disclose information in a manner that enables stakeholders to make an informed analysis of the company's performance. Mouzas (2006: 1125), highlight that effectiveness and efficiency in financial management are focal terms applied in assessing the performance of an organization. According to Rieseneder (2008), effectiveness refers to doing the right things and efficiency doing things right. A measure of effectiveness assesses the ability of an organization to attain its goals and objectives.

The optimisation of finances resources is a measure of the ability of municipalities to achieve targeted outputs by utilising the mínimum amount of input. According to Pillay, et al (2012), sound financial management in the public sector is an important contributor in achieving greater transparency, accountability, efficiency and effectiveness, fiscal responsibility and, hence, improved governance. According to Robbins and Decenzo (2004: 20), skill is the ability to demonstrate a system and sequence of behavior that is functionally related to attaining a performance goal. The availability of skilled personnel within an organization has a significant impact on the effectiveness and efficiency of that organization to carry out its mandate in the manner in which services are delivered. The annual report issued by the City of Tshwane (2015) for the financial year 2013/2014 shows that the municipality received a qualified audit report from the Auditor-General. The City of Tshwane is committed into receiving unqualified audit reports in the years ahead. Attempts have been made to learn from past mistakes and make significant improvements in financial management and proper auditing and accounting. Evans (2011: 288) defines performance management as the extent to which an individual contributes to achieving the goals and objectives of an organization. Good performance is characterized by flexibility, innovation, knowledge and skill in the given projects, alignment with organizational plannings, and customer needs. The Municipal Systems Act 32 of 2000 defines performance management as an iterative process of setting targets, monitoring performance against those targets, and taking steps to improve performance. Financial management can help municipalities to work more effectively towards meeting development challenges, because finance allows them to assess the impact of the various strategies they are pursuing. Finance also enhances accountability, because finance allows municipal councilors and staff, and local communities, to monitor whether they are receiving value for money spent on various services. Finance is also about organizational culture- the attitudes and practices which inform how municipal staff work on a daily basis. Municipalities must promote a culture of performance management in their structures, political offices, and administration. In other words, municipalities must encourage working practices which are economical, effective, efficient and accountable. According to Atkinson (2012: 48), there are three domains in performance management: 
planning, progress review and evaluation. The framework presents an integrated model for the management of organizational performance.

Fahy (2013), argues that quality is only achieved when the product or service is responding to satisfy the stated or implied needs of the customers. The seller or service provider is delivering quality whenever its product or service meets or exceeds the customers' expectations. Understanding the customer requirements is a prerequisite for delivering superior quality because such requirements represent performance standards that customers use in assessing the quality of the product or services. Fahy (2013) points out that competitive financial performance can only be achieved through total quality management (TQM) as the approach to improving quality, productivity and competitiveness in international market place. Many empirical studies proved that firms that have adopted a quality-oriented strategy, achieved improved productivity, customer satisfaction, increase respondent morale, improved management-labor relation and above all, high performance (Hussain, Tsironis \& Ajmal, 2011: 282-295). According to the authors, the critical requirements for efficient service delivery are cost, competitive advantage, reputation and sustainability. In order to practice sound financial performance, employees providing financial services to customers must abide by good governance principles (Sarkar \& Batabyal, 2011: 20-29).

The City of Tshwane utilises an integrated development planning as a means of assessing and evaluating the degree of compliance with the MFMA. The Stakeholder Theory states that stakeholders remain loyal as long as service delivery agreements and expectations of service quality are satisfied (Donaldson \& Preston, 1995: 65-91). Stakeholders need to interact effectively as a means of optimising service delivery. The South African Local Government Authority (SALGA) is mandated with the task of ensuring adequate quality service delivery and sound financial discipline by all municipalities and governments in South Africa. As such, it interacts with stakeholders and municipalities on a regular basis. Its stakeholders are expected to make a collective effort towards advancing the interest of all South Africans. The stakeholder theory indicates that it is not posible for large municipalities such as the City of Tshwane to win the loyalty of customers on a sustainable basis without optimising and ensuring the quality of municipal service delivery to customers at all times.

\section{Methods and Materials of Study}

The study was based on a stratified random simple of size 146 employees of the City of Tshwane who are responsable for the provision of financial, accounting and auditing services to customers who live and conduct business in the various parts of the City of Tshwane. The design of the study was cross-sectional and descriptive as data was collected from the enterprises that took part in the study only once during the period of study. For each one of the 146 employees who were selected for the study, the degree of adherence to the Municipal Finance Management Act (Act 56 of 2003) was assessed by using a composite index defined by Kaiser, Crother, Kelly, Luiselli, O’Shea, Ota, Passos, Schleip \& Wüster (2013: 8-23). Data was collected by using a structured, pre-tested and validated questionnaire of study. Data analyses were performed by using methods such as frequency tables, cross-tab analyses and 
ordered probit regression analysis (Hosmer \& Lemeshow, 2013). Odds ratios obtained from logistic regression analysis were adjusted for potential confounding variables. The reliability of estimated models was assessed based on standard diagnostic procedures. The statistical package STATA version 15 (STATA Corporation, 2018) was used for data entry and analysis.

\section{Results of Study}

Table 1 shows frequency proportions that indicate the degree to which finance staff working in the City of Tshwane in various capacities adhere to sound financial management principles, procedures and guidelines. It can be seen from the table that 130 of the 146 employees who were selected for the study $(89 \%)$ were efficient in financial management, whereas the remaining 16 of the 146 employees $(11 \%)$ were not efficient in financial management. Efficiency in financial management was assessed by assessing the degree of adhere of employees to the Municipal Finance Management Act (Act 56 of 2003) based on a composite index defined by Kaiser, Crother, Kelly, Luiselli, O’Shea, Ota, Passos, Schleip \& Wüster (2013: 8-23).

Table 1. General Assessment of Employees ( $\mathrm{n}=146)$

\begin{tabular}{|c|c|}
\hline Variable of study & Percentage \\
\hline \multirow[t]{2}{*}{ Overall efficiency in financial management } & Efficient: $89 \%$ \\
\hline & Inefficient: $11 \%$ \\
\hline \multirow[t]{5}{*}{ Visibility in implementing financial controls } & Good: $13 \%$ \\
\hline & Above average: $48 \%$ \\
\hline & Average: $29 \%$ \\
\hline & Below average: $10 \%$ \\
\hline & Poor: $0 \%$ \\
\hline \multirow[t]{5}{*}{ Good example set by senior officers } & Good: $14 \%$ \\
\hline & Above average: $35 \%$ \\
\hline & Average: $31 \%$ \\
\hline & Below average: $19 \%$ \\
\hline & Poor: $1 \%$ \\
\hline \multirow[t]{5}{*}{ Supervision of all bank accounts } & Good: $15 \%$ \\
\hline & Above average: $30 \%$ \\
\hline & Average: $38 \%$ \\
\hline & Below average: $16 \%$ \\
\hline & Poor: $1 \%$ \\
\hline \multirow[t]{4}{*}{ Training of financial officers } & Good: $5 \%$ \\
\hline & Above average: $30 \%$ \\
\hline & Average: $33 \%$ \\
\hline & Below average: $31 \%$ \\
\hline
\end{tabular}


Rotation or transfer of financial employees

Rules are observed dutifully

Documenting of financial records

Commitment to sound accounting procedures and guidelines

Tax laws are obeyed dutifully

Procedures are followed rigorously

Separation of key functions is respected

Authorization of expenditures

Computations and costing are verified
Poor: $1 \%$

Good: 0\%

Above average: $16 \%$

Average: 32\%

Below average: $41 \%$

Poor: $11 \%$

Good: $22 \%$

Above average: $38 \%$

Average: $26 \%$

Below average: $12 \%$

Poor: $2 \%$

Good: $19 \%$

Above average: $42 \%$

Average: $23 \%$

Below average: $13 \%$

Poor: $3 \%$

Good: $13 \%$

Above average: $43 \%$

Average: $29 \%$

Below average: $14 \%$

Poor: $1 \%$

Good: $11 \%$

Above average: $56 \%$

Average: $27 \%$

Below average: $6 \%$

Poor: $0 \%$

Good: $8 \%$

Above average: $46 \%$

Average: $38 \%$

Below average: $6 \%$

Poor: $2 \%$

Good: $9 \%$

Above average: $36 \%$

Average: $40 \%$

Below average: $10 \%$

Poor: $5 \%$

Good: $13 \%$

Above average: $49 \%$

Average: $33 \%$

Below average: $3 \%$

Poor: $2 \%$

Good: $12 \%$

Above average: $44 \%$ 


\begin{tabular}{ll}
\hline & Average: $39 \%$ \\
& Below average: $5 \%$ \\
& Poor: $0 \%$ \\
Prevention of over-spending & Good: $19 \%$ \\
& Above average: $37 \%$ \\
& Average: $34 \%$ \\
& Below average: $10 \%$ \\
& Poor: $0 \%$ \\
& Good: $5 \%$ \\
Above average: $35 \%$ & Average: $47 \%$ \\
Belection of fraudulent activities & Poor: $1 \%$ \\
Genalization of wrong activities & Above average: $10 \%$ \\
& Average: $55 \%$ \\
& Below average: $24 \%$ \\
& Poor: $8 \%$ \\
\hline
\end{tabular}

The Pearson chi-square test of association (Hair, Black, Babin, \& Anderson, 2010) was used for performing a preliminary screening of influential factors that were significantly associated with the degree to which employees adhered to the MFMA Act by way of following the basic principles, regulations and guidelines of the Act. A total of 44 tests of associations were performed between the dependent variable of study (degree of adherence to the MFMA Act), and each one of the 44 independent variables of study that are well known to affect the degree to which finance officers adhere to sound financial management principles and guidelines.

Values of the dependent variable of study, Y (Efficiency), were defined as follows:

Efficiency $=\left\{\begin{array}{l}1 \text { if adequate } \\ 2 \text { if inadequate }\end{array}\right.$

Pearson's chi-square tests of association were performed between values of variable $\mathrm{Y}$ and each of the values of 44 factors that are known to affect efficiency in financial management at the City of Tshwane. The results showed that efficiency in sound financial management in the City of Tshwane was significantly associated with 9 of the 44 variables of study at the 5\% level of significance. At the 5\% level of significance, significant two-way associations are characterized by large observed chi-square values and P-values that are smaller than 0.05 . It can be seen from Table 2 that all 9 variables listed in the table are significantly associated with sound financial management at the $5 \%$ level of significance. 


\section{Macrothink}

Table 2. Results Obtained from Cross-Tab Analyses ( $\mathrm{n}=146)$

\begin{tabular}{lcc}
\hline $\begin{array}{l}\text { Factors significantly associated with sound financial } \\
\text { management }\end{array}$ & $\begin{array}{c}\text { Observed } \\
\text { chi-square value }\end{array}$ & P-value \\
\hline Degree of skills in financial accounting and auditing & 11.0206 & 0.000 \\
Duration of service in City of Tshwane & 9.2318 & 0.000 \\
Degree of job satisfaction & 8.2578 & 0.000 \\
Adherence to terms of contracts & 6.1705 & 0.000 \\
Adherence to bidding procedures & 5.7010 & 0.000 \\
Adherence to rules & 4.7010 & 0.001 \\
Training opportunities & 4.8867 & 0.007 \\
Verification of eligibility requirements & 3.7464 & 0.012 \\
Making decisions based on merit & 3.5812 & 0.029 \\
\hline
\end{tabular}

It can be seen from Table 2 that the efficiency of finance staff working in the City of Tshwane on financial management was significantly influenced by degree of skills in financial accounting and auditing, duration of service in City of Tshwane, degree of job satisfaction, adherence to terms of contracts, adherence to bidding procedures, adherence to rules, training opportunites, verification of eligibility requirements, and making decisions based on merit, in a decreasing order of strength. The 9 predictor variables shown in Table 2 were subsequently used for performing binary logistic regression analysis.

Table 3. Comparison with Regards to Efficiency in Financial Management $(n=146)$

\begin{tabular}{|c|c|c|}
\hline $\begin{array}{l}\text { Factors significantly associated with efficiency } \\
\text { in financial management }\end{array}$ & Efficient (n1=130) & Inefficient $(\mathrm{n} 2=16)$ \\
\hline \multirow{2}{*}{$\begin{array}{l}\text { Degree of skills in financial accounting and } \\
\text { auditing }\end{array}$} & Yes: $72 \%$ & Yes: $8 \%$ \\
\hline & No: $5 \%$ & No: $15 \%$ \\
\hline \multirow[t]{2}{*}{ Duration of service in City of Tshwane } & Yes: $72 \%$ & Yes: $8 \%$ \\
\hline & No: $5 \%$ & No: $15 \%$ \\
\hline \multirow[t]{2}{*}{ Degree of job satisfaction } & Yes: $73 \%$ & Yes: $15 \%$ \\
\hline & No: $4 \%$ & No: $8 \%$ \\
\hline \multirow[t]{2}{*}{ Adherence to terms of contracts } & Yes: $70 \%$ & Yes: $16 \%$ \\
\hline & No: $7 \%$ & No: $7 \%$ \\
\hline \multirow[t]{2}{*}{ Adherence to bidding procedures } & Yes: $70 \%$ & Yes: $16 \%$ \\
\hline & No: $7 \%$ & No: $7 \%$ \\
\hline \multirow[t]{2}{*}{ Adherence to rules } & Yes: $57 \%$ & Yes: $11 \%$ \\
\hline & No: $20 \%$ & No: $12 \%$ \\
\hline \multirow[t]{2}{*}{ Training opportunities } & Yes: $42 \%$ & Yes: $6 \%$ \\
\hline & No: $35 \%$ & No: $17 \%$ \\
\hline \multirow[t]{2}{*}{ Verification of eligibility requirements } & Yes: $42 \%$ & Yes: $6 \%$ \\
\hline & No: $35 \%$ & No: $17 \%$ \\
\hline \multirow[t]{2}{*}{ Making decisions based on merit } & Yes: $57 \%$ & Yes: $11 \%$ \\
\hline & No: $20 \%$ & No: $12 \%$ \\
\hline
\end{tabular}


Table 3 shows a comparison between 2 categories of finance employees with regards to the 11 significant factors identified above. Category 1 consists of 130 employees (89\%) who have adequate efficiency in financial management. Category 2 consists of 16 employees (11\%) who lack efficiency in sound financial management.

It can be seen from Table 3 that respondents in categories 1 and 2 differ from each other with regards to degree of skills in financial accounting and auditing, duration of service in City of Tshwane, degree of job satisfaction, adherence to terms of contracts, adherence to bidding procedures, adherence to rules, training opportunities, verification of eligibility requirements, and making decisions based on merit. Efficient employees were found to be relatively more prudent and rule-bound on fiscal issues.

Results from binary logistic regression analysis are theoretically more reliable than results from Pearson's chi-square tests of association (Hosmer \& Lemeshow, 2013). This is because the measure of effect in binary logistic regression is the odds ratio, and not P-values obtained from two-by-two cross-tab tests. Logistic regression analysis allows multivariate analysis involving several variables that are influential over the extent to which finance staff working for the City of Tshwane are efficient in financial management. It is also possible to assess the reliability of the fitted logistic regression model based on highly reliable diagnostic tests such as the classification table, the likelihood ratio test, the Hosmer-Lemeshow goodness-of-fit tests, sensitivity and specificity. Binary logistic regression of analysis was performed by performing the regression of variable $\mathrm{Y}$ (Efficiency in financial management) on the 9 variables of study that were found to be significantly associated with efficiency in financial management. At the 5\% level of significance, influential predictors of efficiency in financial management have odds ratios that are significantly different from 1, P-values that are smaller than 0.05 , and $95 \%$ confidence intervals of odds ratios that do not contain 1 .

Table 4. Odds Ratios Estimated from Ordered Probit Regression ( $\mathrm{n}=146)$

\begin{tabular}{lcccc}
\hline Variable & P-value & Odds Ratio & \multicolumn{2}{c}{$\begin{array}{c}\text { 95\% Confidence Intervals of } \\
\text { Odds Ratio }\end{array}$} \\
\hline Skills in financial management & 0.000 & 3.68 & $(1.74$, & $7.09)$ \\
Duration of service & 0.000 & 3.26 & $(1.58$, & $6.69)$ \\
Degree of job satisfaction & 0.000 & 2.87 & $(1.44$, & $5.37)$ \\
\hline
\end{tabular}

Accordingly, 3 of the variables used for binary logistic regression analysis were highly influential predictors of efficiency in financial management. These 3 predictor variables of study were degree of skills in financial management, duration of service in the City of Tshwane, and degree of job satisfaction, in a decreasing order of strength.

\section{Interpretation of Odds Ratios}

The odds ratio of the variable "skills in financial management" is equal to 3.68. This indicates that a finance employee who lacks skills in financial management is 3.68 times 
more likely to be inefficient in financial management in comparison with another finance employee who possesses adequate skills in financial management.

The odds ratio of the variable "duration of service" is equal to 3.26. This indicates that a finance employee who has not served the City of Tshwane for 5 years or more is 3.26 times more likely to be inefficient in financial management in comparison with another finance employee who has served the City of Tshwane for 5 years or more.

The odds ratio of the variable "degree of job satisfaction" is equal to 2.87. This indicates that a finance employee who lacks job satisfaction while working for the City of Tshwane is 2.87 times more likely to be inefficient in financial management in comparison with another finance employee who enjoys job satisfaction while working for the City of Tshwane.

The percentage of overall correct classification for the fitted binary logistic regression model was equal to $84.29 \%$. This figure is above $75 \%$, and shows that the fitted binary logistic regression model is highly reliable. The $\mathrm{P}$-value obtained from the Hosmer-Lemeshow goodness-of-fit test was equal to $0.3295>0.05$. This indicates that there was no reason to doubt the reliability of the fitted binary logistic regression model.

\section{Discussion of Results}

The key finding of study was that $89 \%$ of the 146 employees who took part in the study adhered adequately to the Municiapl Finance Management Act based on the criterion set out by Kaiser, Crother, Kelly, Luiselli, O’Shea, Ota, Passos, Schleip \& Wüster (2013: 8-23), whereas the remaining $11 \%$ of employees did not adhere to the Act adequately by the same criterion. This figure sounds good considering the fact that Tshwane is a developing municipality.

Results obtained from cross-tab analyses showed that the efficiency of finance staff working in the City of Tshwane on financial management was significantly influenced by the degree of skills in financial accounting and auditing, duration of service in City of Tshwane, degree of job satisfaction, adherence to terms of contracts, adherence to bidding procedures, adherence to rules, training opportunities, verification of eligibility requirements, and making decisions based on merit. Efficient employees were found to be relatively more prudent and rule-bound on fiscal issues.

Results obtained from binary logistic regression analysis showed that the degree of adherence of employees to the Municipal Finance Management Act was significantly influenced by 3 factors. These 3 factors were degree of skills in financial accounting and auditing, duration of service, and degree of job satisfaction, in a decreasing order of strength. The results also showed that there was a statistically significant association between the quality of financial and auditing services that were provided to customers and the degree of adherence to the Municipal Finance Management Act.

According to Achrya, Philippon, Richardson and Roubini (2009: 42-51), the City of Tshwane should develop a model for good governance as a means of supporting stakeholders who expect quality service delivery from the municipality. The view of the City of Tshwane is that 
good governance models in financial management must be used for encouraging financial management employees to improve their performance. There are suitable models that could be used for identifying potential risks that are associated with financial management in municipalities such as the City of Tshwane. Such models are useful for implementing policies from the South African Local Government Authority (SALGA), and for minimizing the risk involved in wasting financial resources that are meant for providing essential municipal services to residents of Tshwane. Good governance entails transparency, accountability and fairness in the administration of public finance. Finance employees working for the City of Tshwane must reflect such essential attributes in their daily activities (Adams \& Mehran, 2003: 123-142).

Meeting the needs of the present without compromising the long-term sustainability requires the sound financial management practices. They underpin the process of democratic accountability. Weak or opaque financial management results in the misdirection of resources and increases the risk of corruption and abuse of resources. The key objective of the Municipal Finance Management Act (2003) (MFMA) is to modernize municipal financial management in South Africa so as to lay a sound financial base for the sustainable delivery of services. It gives guidance in the following components: planning and budgeting, revenue, cash and expenditure management, procurement, asset management, reporting and oversight. Each component contributes to ensuring that expenditure is developmental, effective and efficient and that local municipalities can be held accountable (Amit \& Schoemaker, 2013: 33-46).

According to Andres and Vallelado (2008: 2570-2580), good governance on financial issues could take several years to bear tangible results in local municipalities. The research work done by the author's shows that adherence to MFMA regulations and guidelines by local municipalities is a key requirement for ensuring optimal utilization of public finance and resources. According to Bebchuk, Cohen and Ferrell (2009: 783-827), the reforms introduced by the MFMA are quite helpful for ensuring overall economic growth in South Africa, and for preserving the credit rating South Africa has at the moment. The MFMA is the cornerstone of the broader reform package for local government outlined in the 1998 White Paper on Local Government. The MFMA was introduced in 2003. At that time, the system of local government finance was characterized by practices such as one-year line-item budgeting, which did not support strategic planning and the alignment of budgets with priorities over the medium term. This generally resulted in councils allocating resources based on historical commitments rather than looking at current priorities and the future needs of communities. The allocations of resources were not done based on municipal finance practices by effective and efficient officials. This resulted in a culture of poor performance and irregular or inaccurate reporting. Some reports were containing too much data and too little useful information. Some municipalities were unable to publish and submit the annual financial statements for audit on time or at all. Because of this behaviour, significant strides have been made with implementing the new financial management arrangements spelt out in the MFMA. However, progress is still poor and many municipalities need to implement both the letter and the spirit of the MFMA. This is to enable managers to manage' within a framework of regular and consistent reporting so that they can be held accountable for their decisions and actions on financial matters by the 
City of Tshwane (Brunnermeier, 2009: 77-100).

The research work conducted by Beetsma, Giuliodori, De Jong and Widijanto (2013: 83-101) shows that the key mechanisms for strengthening accountability include routine accounting, auditing and reporting on a month-by-month basis. The set of legislation governing local government provides for a number of mechanisms for strengthening accountability. The first mechanism involves separating and clarifying roles and responsibilities of mayors, executive councillors, non-executive councillors and officials. The separation of roles is critical in the local government and is affecting good governance negatively. The executive mayor and executive committee are expected to provide political leadership, by proposing policies, guiding the development of budgets and performance targets, and overseeing their implementation by monitoring performance through in-year reports. In executing their duties, they may not use their position, privileges or confidential information for private gain or to improperly benefit another person. The municipal manager and other senior officials are responsible for financial management, implementation and outputs in terms of the MFMA. They have a duty to act with fidelity, honesty and integrity and in the best interests of the municipality at all times. Non-executive councillors, as elected representatives of the community, debate and approve the proposed policies and budgets and also oversee the performance of the municipality. They are also responsible for quarterly and annual reports performance. Ensuring fiscal discipline and the culture of accurate and prompt financial reporting is essential for sustained economic growth in developing nations such as South Africa (Buckley \& Ghauri, 2012: 81-98).

According to Calvin (2012: 49-52), public finance and resources must not be spent on plans of actions that have not been duly approved by a competent, transparent and accountable planning committee. All expenditures must be attached to performance management contracts in which public money is accounted for thoroughly and methodically. This explains why the City of Tshwane must rely on a performance monitoring and evaluation mechanism as a means of minimizing unwarranted expenditure. The second mechanism involves developing a performance orientation. The legal framework introduces requirements and processes for establishing service delivery priorities and plans. The aim is to ensure alignment between the plans, budgets, implementation actions and reporting to ensure proper management accountability for the achievement of service delivery targets. The third mechanism involves strengthening quarterly and annual reporting, and disclosure requirements. High quality and timely management information allows management to be proactive in identifying and solving problems as they arise. This also strengthens the separation of roles and supports the performance orientation in the municipalities. According to Chao, Szerek, Pereira and Pauly (2010: 231-242), plans of actions approved by municipalities and local governments must be aligned with reporting. The South African Constitution guarantees all South Africans the right to live in municipalities in which public resources and finance are not abused or misappropriated by corrupt or inefficient officials. Section 153 of the South African Constitution demonstrates that a municipality must manage its resources effectively and efficiently to give priority to the basic needs of the community, and to promote the social and economic development of the entire community. 
According to Elder and Serletis (2010: 1137-1159), it is a constitutional duty of all democratically elected governments to publish financial statements that are openly accessible to all stakeholders that have key components of sound financial management guided by the MFMA, together with the Municipal Systems Act (2000). The key components of sound financial management are routine accountability, auditing and reporting (Elliot \& Boshoff, 2013: 44-58). Monitoring and evaluation mechanisms are often used for ensuring sound financial management in local government and municipalities such as the City of Tshwane. This is done by using an integrated development plan (IDP) that sets out the municipality's goals and development plans, which need to be aligned with the municipality's available resources. Council uses the IDP to undertake an annual review and assessment of performance based on the annual report. Budgets must be approved by following recommended procedures by all relevant stakeholders in order to be implemented. Budgets must be audited, assessed and evaluated on a regular basis. Budgets must be used for performance management and assessment. Local municipalities often use 3-year budgets that are meant for setting out the revenue raising and expenditure plan of the municipality for approval by council. The allocation of funds needs to be aligned with the priorities in the IDP. Service delivery and budget implementation plan (SDBIP) are viewed as the cornerstone for monitoring and evaluation of programmes that are run by local governments and municipalities. The SDBIP states that, the service delivery targets and financial targets must be aligned with the annual targets monthly or quarterly. As the municipality's implementation plan, it lays the foundations for the performance agreements of all senior management. The approach implemented in the Service delivery and budget implementation plan is consistent with what has been recommended by Fahlenbrach \& Stulz (2011: 11-26).

Routine monthly and quarterly reports are used in local governments and municipalities for ensuring the implementation of approved plans of actions at regular interval, and for minimizing the expenditure of public finance on plans of action that have not been approved. The administration reports to council on the implementation of the budget and SDBIP through monthly, quarterly and mid-year reports. These reports are used to monitor the performance of financial targets and service delivery targets. Annual financial statements are vital for assessing efficiency in service delivery. Such reports are essential or assessing overall progress and the cost of service delivery. The reports are essential for monitoring and evaluation in the public service sector. Such reports provide an overall picture of the budget approved, and how much work has been done by using the approved budget. Local municipalities can also use such reports for auditing purposes, and reflect the financial position of the municipality at regular intervals. The reports are also essential for making a submission to the Auditor-General based on a comprehensive assessment on all known expenditures and key performance indicators on which satisfactory progress has been made in the financial year. The City of Tshwane is committed to obtaining unqualified audit reports from the Auditor-General. To do so, the City of Tshwane must bolster the culture of fiscal discipline and sound financial management in the municipality. Fiscal discipline is highly recommended to municipalities and local governments in developing nations (Fauconnier \& Mathur-Helm, 2013: 1-14).

According to Grant (2013: 114-135), the task of reforming municipal financial management is 
a lengthy and challenging process. The introduction of the MFMA in 2003 laid the foundation for sound financial management. Since then, the requirements with supply chain management, public private partnerships, the minimum skills and competencies in the municipal finance officials and asset transfers were set in place. Each discipline aims to build and reinforce on the bases laid by previous initiatives, taking into consideration the time needed for municipal systems and practices to change. Since 2008, the South African National Department of Finance has been giving specific attention to strengthening municipal budgeting and reporting practices. Major Key initiatives have been the introduction of the Municipal Budget and Reporting Regulations in 2009, the enforcement of monthly, quarterly and mid-year financial reporting processes and firmer management of conditional grants in accordance with the annual Division of Revenue Act. These disciplines have been supported by strengthening National Treasury's local government database and by publishing an increasing range of local government financial information on National Treasury's website. National Treasury is currently working on introducing a standard chart of accounts for municipalities to ensure high sound financial management practices which will empower a council to make more informed decisions on the performance and sustainable, effective and efficient service provision. The generic municipal budget cycle is set out in the MFMA and described in MFMA circular 19 with the planning phases. This schedule sets key target dates for the budget process. The planning phase involves the strategic review of the IDP, setting service delivery objectives for the next three years, consultation on tariffs, indigent policy, credit control and free basic services, and reviewing the previous year's performance and current economic and demographic trends. The process has a phase for preparation that involves the analysis of revenue and expenditure projections (based on the mid-year budget and performance assessment), revising budget related policies and considering local, provincial and national priorities, a tabling and public consultation phase, which requires the mayor to table a proposed budget, IDP revisions and budget policies in council by the end of March. Thereafter, the municipality is required to conduct public budget consultations during April.

The research work conducted by Beck and Demirguc-Kunt (2012: 2931-2943) and Bharadwaj (2013: 169-196) has shown that small and medium-sized businesses that conduct businesses in municipalities have the potential for providing the financial means that is needed for creating jobs as well as the alleviation of urban poverty and unemployment. In this regard, local governments and municipalities can benefit from adhering to guidelines and regulations that are recommended in the MFMA documents. Proper documents that are prepared in accordance with MFMA rules are required to submit an annual report for each financial year. The annual report is the key instrument of transparent governance and accountability and must be used to report on performance for the year. On time completion and submission of annual reports and annual financial statements, facilitate timely oversight. Oversight of the annual report represents the final stage in the accountability cycle. Once approved by the council, the annual report must be placed on the municipal website, made available to the wider community and copies must be sent to various stakeholders. Audit opinions issued by the Auditor-General are the most important part of the auditor's report provided to the municipality. The audit findings are based on an independent and often extensive verification process of the annual financial statements and the performance information in the annual report. The study conducted by Carr 
(2013: 41-49) has shown that good governance on financial management entails transparency, accountability and the implementation of municipal bylaws and regulations on fiscal matters with vigour. Wade and Hulland (2013: 107-142) have shown that sound financial management is a key requirement for the efficient utilization of municipal resources in developing nations such as South Africa.

Governance analysis constitutes mechanisms that are used for the assessment of key deliverables. Analysis of policy includes the setting up of chains, the evaluation of chains, and the need to make amendments based on what is required for efficient service delivery. A good business plan is useful for analysis and evaluation. Business plans take financial issues into account, and are practical. The analysis of performance must account for discrepancies between expected outputs and tangible results. Major discrepancies must be accounted for by those who are responsible. The issue of leadership is crucial for sound financial management. Leading by example is the most important tool for prudent financial management in the City of Tshwane and other local governments and municipalities. Studies conducted by Kirsten \& Rogerson (2012: 29-59) and Kovacevic (2012: 12-15) show that ensuring fiscal discipline in local governments and municipalities a key requirement for growing small and medium-sized business enterprises on a sustainable basis.

\section{References}

Achrya, V., Philippon, T., Richardson, M. \& Roubini, N. (2009). The financial crisis of 2007-2009: Causes and remedies. New York: John Wiley \& Sons. https://doi.org/10.1111/j.1468-0416.2009.00147_2.x

Amit, R., \& Schoemaker, P. J. H. (2013). Strategic Assets and Organizational Rent. Strategic Management Journal, 14(1), 33-46. https://doi.org/10.1002/smj.4250140105

Andres, P., \& Vallelado, E. (2008). Corporate governance in banking: the role of the board of directors. Journal of Banking and Finance, 32(1), 2570-2580. https://doi.org/10.1016/j.jbankfin.2008.05.008

Atkinson, M. (2012). Developing and using a performance management framework: a case study. International Journal of Productivity and Performance Management, 16(3), 47-56. https://doi.org/10.1108/13683041211257402

Barnes, D. (2009). Operations management: An international perspective. New York: Thomson.

Bebchuk, L. A., Cohen, A. \& Ferrell, A. (2009). What matters in corporate governance? Review of Financial Studies, 22(1), 783-827. https://doi.org/10.1093/rfs/hhn099

Beck, T. \& Demirguc-Kunt, A. (2012). Small and medium-size enterprises: access to finance as a growth constraint. Journal of Banking and Finance, 30(11), 2931-2943. https://doi.org/10.1016/j.jbankfin.2006.05.009

Beetsma, R., Giuliodori, M., De Jong, F., \& Widijanto, D. (2013). Spread the news: the impact 
of news on the European sovereign bond markets during the crisis. Journal of International Money and Finance, 34(1), 83-101. https://doi.org/10.1016/j.jimonfin.2012.11.005

Bharadwaj, A. (2013). A Resource-Based Perspective on Information Technology Capability and Firm Performance: An Empirical Investigation. MIS Quarterly, 24(1), 169-196. https://doi.org/10.2307/3250983

Bhatt, G. D., \& Grover, V. (2013). Types of Information Technology Capabilities and Their Role in Competitive Advantage: An Empirical Study. Journal of Management Information Systems, 22(2), 253-277. https://doi.org/10.1080/07421222.2005.11045844

Blaikie, N. (2010). Designing social research (2nd ed.). London: Polity Press.

Block, S. B., Hirt, G. A., \& Danielsen B. R. (2009). Foundations of Financial Management. New York: McGraw-Hill/Irwin.

Brunnermeier, M. K. (2009). Deciphering the liquidity and credit crunch 2007-2008. Journal of Economic Perspectives, 23(1), 77-100. https://doi.org/10.1257/jep.23.1.77

Buckley, P. J., \& Ghauri, P. N. (2012). Globalisation, Economic Geography and the Strategy of Multinational Enterprises. Journal of International Business Studies, 35(2), 81-98. https://doi.org/10.1057/palgrave.jibs.8400076

Calvin, R. J. (2012). Entrepreneurial Management. New York: McGraw-Hill.

Carr, N.G. (2013). IT doesn't matter. Harvard Business Review, 3(4), 41-49.

Chao, L. W., Szrek, H., Pereira, N. S., \& Pauly. M. V. (2010). Too sick to start: Entrepreneur's health and business entry in Townships around Durban, South Africa. Journal of Developmental Entrepreneurship, $\quad$ 231-242. https://doi.org/10.1142/S108494671000152X

City of Cape Town. (2018). Annual report for 2016/2017. Retrieved 25 June 2019 from: http://www.capetown.gov.za/

City of Tshwane. (2018). Annual report for 2016/2017. Retrieved 25 June 2019 from: http://www.tshwane.gov.za/

Dick, G. P. M., Gal Limore, K., \& Brown, J. C. (2009). Exploring performance attribution: the case of quality management. International Journal of Productivity and Performance Management, 58(4), 311-328. https://doi.org/10.1108/17410400910950991

Donaldson, T., \& Preston, L. E. (1995). The stakeholder theory of the corporation: Concepts, evidence, and implications. Academy of management Review, 20(1), 65-91. https://doi.org/10.5465/amr.1995.9503271992

Edoho, F. M. (2015). Entrepreneurialism: Africa in transition. African Journal of Economic and Management Studies, 6(2), 127-147. https://doi.org/10.1108/AJEMS-03-2013-0030

Elder, J., \& Serletis, A. (2010). Oil price uncertainty. Journal of Money Credit and Banking, 
42(1), 1137-1159. https://doi.org/10.1111/j.1538-4616.2010.00323.x

Elliot, R., \& Boshoff, C. (2013). The influence of organisation factors in small tourism businesses on the success of internet marketing. Management Dynamics, 14(3), 44-58.

Engelbrech, L. (2009). Codes of Governance Principles. Johannesburg: Institute of Directors in Southern Africa.

Evans, J. R. (2011). Quality Management, Organization, and Strategy (6th ed.). South Western: Cengage Learning.

Fahlenbrach, R., \& Stulz, R. M. (2011). Bank CEO incentives and the credit crisis. Journal of Financial Economics, 99(1), 11-26. https://doi.org/10.1016/j.jfineco.2010.08.010

Fahy, J. (2013). The resource-based view of the firm: some stumbling-blocks on the road to understanding sustainable competitive advantage. Journal of European Industrial Training, 21(2), 94-104. https://doi.org/10.1108/03090590010321061

Fauconnier, A., \& Mathur-Helm, B. (2013). Black economic empowerment in the South African industry: A case study of Exxaro limited. South African Journal of Business Management, 39(4), 1-14. https://doi.org/10.4102/sajbm.v39i4.567

Ferreira, E. J., \& Campher, K. (2010). Office Finance. Cape Town: Juta \& Company.

Gereffi, G., \& Sturgeon, T. (2013). Global value chains in a changing world. Geneva: World Trade Organization.

Grant, R. M. (2013). The Resource-based Theory of Competitive Advantage. California Management Review, 33(3), 114-135. https://doi.org/10.2307/41166664

Gumede, V. (2012). Import demand elasticity's for South Africa: A co-integration analysis. Journal for Studies in Economics and Econometrics, 24(1), 21-28.

Hair, J. F., Black, W. C., Babin, B. J., \& Anderson, R. E. (2010). Multivariate Data Analysis: A Global Perspective. London: Pearson.

Hamann, R., Khagram, S., \& Rohan, S. (2008). South Africa's charter approach to post-apartheid economic transformation: Collaborative governance or hardball bargaining. Journal of South African Studies, 34(1), 21-37. https://doi.org/10.1080/03057070701832866

Hau, H., \& Thum, M. P. (2009). Subprime crisis and the board. Economic Policy, 24(1), 701-751. https://doi.org/10.1111/j.1468-0327.2009.00232.x

Henrekson, M. (2014). Entrepreneurship, innovation, and human flourishing. Small Business Economics, 43(3), 511-528. https://doi.org/10.1007/s11187-014-9551-y

Hoque, A. S. (2011). Accountability and governance: strengthening extra-bureaucratic mechanisms in Bangladesh. International Journal of Productivity and Performance Management, 60(1), 59-74. https://doi.org/10.1108/17410401111094312 
Hosmer, D. W., \& Lemeshow, S. (2013). Applied Logistic Regression Analysis. New York: John Wiley \& Sons. https://doi.org/10.1002/9781118548387

Hussain, M., Tsironis, L., \& Ajmal, M. M. (2011). A quality function development strategy for improving customer satisfaction: case study of telecom companies of Pakistan. Asian Journal on Quality, 12(3), 282-295. https://doi.org/10.1108/15982681111187119

Ja“A“Skela, I. A., \& Lo“Nnqvist, A. (2011). Public service productivity: how to capture outputs? International Journal of Public Sector Management, 24(4), 289-302. https://doi.org/10.1108/09513551111133461

Kaiser, H., Crother, B.I., Kelly, C.M., Luiselli, L., O’Shea, M., Ota, H., Passos, P., Schleip, W.D., \& Wuster, W. (2013). Best practices: in the 21 st century, taxonomic decisions in herpetology are acceptable only when supported by a body of evidence and published via peer-review. Herpetological Review, 44(1), 8-23.

Kalof, L., Dan, A., \& Dietz, T. (2008). Essential of Social Research (1st ed.). The McGraw-Hill Open University Press, New York, NY.

Keh, H. T., Chu, S., \& Xu, J. (2006). Efficiency, effectiveness and productivity of marketing in services. European Journal of Operational Research, 170(1), 265-276. https://doi.org/10.1016/j.ejor.2004.04.050

Kirsten, M., \& Rogerson, C. M. (2012). Tourism, business linkages and small enterprise development in South Africa. Development Southern Africa, 19(1), 29-59. https://doi.org/10.1080/03768350220123882

Kovacevic, N. (2012). Righting wrongs: Affirmative action in South Africa. Harvard International Review, 6(1), 12-15.

Laeven, L., \& Levine, R. (2007). Is there a diversification discount in financial conglomerates? Journal of Financial Economics, 85(1), 331-367. https://doi.org/10.1016/j.jfineco.2005.06.001

Lovelock, C., Wirtz, J., \& Chew, P. (2009). Relationship marketing: Essentials of Services Marketing. Singapore: Prentice Hall.

Marx, J. (2010). Finance for Non-Financial Manager (2nd ed.). Pretoria: Van Schaik.

Marx, J., Swardt, C., Smith, M.B., \& Erasmus, P. (2009). Financial Management (3rd ed.). London: Pearson.

Mcelroy, B., \& Mills, C. (2007). Managing stakeholders. Gower Handbook of Project Management (1st ed.). Gower Publishing: Aldershot.

Mitchell, R. K., Agle, B. R., \& Wood, D. J. (1997). Toward a theory of stakeholder identification and salience: defining the principle of who and what really counts. The Academy of Management Review, 22(4), 853-886. https://doi.org/10.5465/amr.1997.9711022105 
Mouzas, S. (2006). Efficiency versus effectiveness in business network. Journal of Business Research, 59(10/11), 1124-1132. https://doi.org/10.1016/j.jbusres.2006.09.018

Nguyen, N. H., Skitmore, M., \& Wong, J. K. W. (2009). Stakeholder impact analysis of infrastructure project management in developing countries: a study of perception of project managers in state-owned engineering firms in Vietnam. Construction Management and Economics, 136(5), 1129-1140. https://doi.org/10.1080/01446190903280468

Novy-Marx, R., \& Rauh, J. (2011). Public pension promises: how big are they and what are they worth? The Journal of Finance, 66(4), 1211-1249. https://doi.org/10.1111/j.1540-6261.2011.01664.x

Radnor, J. Z., \& Barnes, D. (2007). Operational Performance Management. International Journal of Productivity and Performance Management, 56(5/6), 384-396. https://doi.org/10.1108/17410400710757105

Rieseneder, F. B. (2008). Good Governance: Characteristics, Methods and the Australian Examples. Transylvanian Review of Administration Sciences, 24, 26-29

Rocha, M. A., \& Sharma, B. (2008). Joint Evalustion of Citizen' Voice and Accountability Report. London: DFID.

Sarkar, T., \& Batabyal, A. K. (2011). Evaluation of customer satisfaction in R\&D organization: a conceptual framework. Asian Journal on Quality, 12(1), 20-29. https://doi.org/10.1108/15982681111140525

South African Auditor-General. (2018). Consolidated general report on the audit finance outcomes of local government 2016/2017. Retrieved 25 June 2019 from: http://www.politicsweb.co.za/politicsweb/view/

South African Chamber Of Commerce and Industry. (2018). Business confidence index Press release. Retrieved 25 June 2019 from: http://www.sacci.org.za/

South African Government Communication and Information Systems. (2003). Municipal Finance Management Act (Act 56 of 2003). Pretoria: South African Government Communication and Information System.

South African National Department of Trade and Industry. (2018). Annual report for 2016/2017. Retrieved 25 June 2019 from www.dti.gov.za

Stata Corporation. (2018). User's guide for STATA version 15. College Station, Texas: STATA Corporation.

Steinbart, P., \& Romney, M. (2006). Accounting Information Systems (10th ed.). New Jersey: Prentice Hall.

Thompson, A. A, Strickland, A. J., \& Gramble, J. E. (2007). Crafting and executing strategy: The quest for competitive advantage (15th ed.). International: McGraw-Hill. 
Van Der Waldt, G. (2006). Managing local government performance: key consideration and challenges. Journal of Public Administration, 41(2), 129-131.

Van Renseburg, M., Ambe, C. M., Evangelou, O., Govender, Koortzen, P. J., Ziemerink, J. E. E., \& Plant, G. J. (2011). Cost and Management Accounting (2nd ed.). Cape Town: Van Schaik.

Waddock, S. A., Bodwell, C., \& Graves, S. B. (2002). Responsibility: the new business Imperative. Academy of Management Executive, 16(2), 132-148. https://doi.org/10.5465/ame.2002.7173581

Wade, M., \& Hulland, J. (2013). Review: Resource-Based View of IS Research. MIS Quarterly, 28(1), 107-142. https://doi.org/10.2307/25148626

Watson, D., \& Head, A. (2010). Principle \& Practice of Corporate finance (5th ed.). England: Prentice Hall.

Wu, D., Thames, J. L., Rosen, D.W., \& Schaefer, D. (2013). Enhancing the product realization process with cloud-based design and manufacturing systems. Journal of Computing and Information Science in Engineering, 13(4), 041004. https://doi.org/10.1115/1.4025257

\section{Copyright Disclaimer}

Copyright for this article is retained by the author(s), with first publication rights granted to the journal.

This is an open-access article distributed under the terms and conditions of the Creative Commons Attribution license (http://creativecommons.org/licenses/by/3.0/). 